\title{
Konferencia a nemzetállami lét kérdéseiről Kelet- Európában, Oroszországban és Eurázsiában
}

\author{
Conference on nation statehood in Eastern Europe, \\ Russia and Eurasia \\ (Third Annual Tartu Conference on Russian and East \\ European Studies - University of Tartu, 10-12 June 2018)
}

\section{KŐSZEGI MARGIT}

\begin{abstract}
KŐSZEGI Margit: tudományos munkatárs, Eötvös Loránd Tudományegyetem, Természettudományi Kar, Földrajz- és Földtudományi Intézet, Regionális Tudományi Tanszék; 1117 Budapest, Pázmány Péter sétány 1/C.; koszegi.margit.email@gmail.com; https:// orcid.org/0000-0002-2494-8328
\end{abstract}

\begin{abstract}
Margit KÖSZEGI: research fellow, Department of Regional Science, Institute of Geography and Earth Sciences, Faculty of Science, Eötvös Loránd University; Pázmány Péter sétány 1/C., H-1117 Budapest, Hungary; koszegi.margit.email@gmail.com; https://orcid.org/0000-0002-2494-8328
\end{abstract}

Harmadik alkalommal rendeztek Észtország neves egyetemvárosában, Tartuban konferenciát az orosz és kelet-európai, illetve általában az egykori Szovjetunióhoz tartozó eurázsiai térséget vizsgáló társadalomkutatók eredményeinek megvitatására. A téma aktualitását és a konferencia népszerüségét egyaránt mutatja, hogy több tudományterületről (történelem, politikatudományok, nemzetközi tanulmányok, kulturális antropológia, földrajz) igen jelentős volt a jelentkezettek száma, valamint bővült az érdeklődők köre az előadók intézményi hátterének területi elhelyezkedését tekintve is. A résztvevők létszámának ugrásszerű növekedése a szervezők részéről korlátozások bevezetését tette szükségessé: az előadások szürése lehetőséget adott a konferencia színvonalának emelésére, ugyanakkor a szervezők deklarált szempontja volt a nemzetközi jelleg erősítése is (minél szélesebb intézményi és területi lefedettséget biztosítva).

A konferencia témájának idén a nemzetállamiságot, a térségben egy évszázada jellemző és meghatározó politikai, kulturális és gazdasági keretrendszert választották. A konferenciát szervező konzorcium három felsőoktatási intézmény, Tartu, Uppsala és Kent egyetemeinek együttmúködésével jött létre, kooperációjukat az Európai Unió Horizon 2020 programja is támogatta az elmúlt években. A párhuzamos szekciókban négy-öt, témájában lehetőség szerint egy-

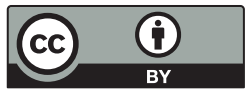


mással összefüggő előadás kapott helyet. A szervezés sajátossága, hogy az egyes szekciók vezetői mellett felkért hozzászólók méltatták a tudományos eredményeket, ütköztették a különböző szempontokat. A szekciók végén a hallgatóság is lehetőséget kapott a kérdésekre, hozzászólásokra, ami szintén érdemi eszmecserék kialakulását segítette elő.

A Tartui Egyetem impozáns fóépületének dísztermében tartott rövid köszöntő után vitaindító előadással, majd állófogadással kezdődött vasárnap este a konferencia. A meghívott előadó, a Harvard Egyetem professzora, Grzegorz Ekiert a kelet-európai államok demokratikus berendezkedésének felemás viszonyaira és újraértelmezett tekintélyelvűségére hívta fel a figyelmet. A nemzetközi tanulmányokkal, összehasonlító politikatudománnyal foglalkozó neves kutató Lengyelország és Magyarország példáján mutatta be az autoriter hatalom újraéledését, az euroszkepticizmus erősödését, a kelet-európai demokrácia válságát. Szemléletmódját erőteljesen meghatározta az amerikai demokrácia felsőbbrendűsége és az előadó konzervativizmussal szembeni ellenszenve, aminek hatására a hallgatóság számára megosztó (ezáltal szó szerint vitaindító) volt közvetített véleménye.

A vasárnap esti témafelvetés keretet adott a konferencia egyik fö gondolatkörének: a demokratikus intézményrendszer, a társadalmi berendezkedési forma és az életérzés érvényesülési lehetőségei korlátozottak, nehez(ebb)en megvalósíthatók Európa keleti felében; sokkal inkább átvett viselkedésformák összességeként jelentkezik, ami a helyi társadalmakban sajátos hibriditást idéz elő. Hasonló keretet adott a hétfo" esti előadás is. Az oxfordi egyetem professzor asszonya, a Brit Akadémia tagja, Catriona Kelly a szovjet és orosz identitás nemzeti és birodalmi jellegét vizsgálta történelmi időléptékben (1881 és 2018 között). Az orosz kultúra (különösen a szovjet periódus) nemzetközileg ismert szakértője a birodalmat építő központi hatalom helyi sajátosságokhoz való viszonyának érdekes epizódjait mutatta be. A konferencián elhangzó előadások másik fö gondolatköre ehhez kapcsolódik: a térség nemzetállamainak létét az Oroszország által meghatározott keretrendszerbe helyezték a résztvevők; így a térség társadalmi folyamatainak posztkolonialista értelmezése hatotta át az előadásokat, kerekasztal-beszélgetéseket.

A konferencia további két napján reggel kilenc órától délután negyed ötig zajlottak a párhuzamos szekció-előadások, amelyek között kávé- és ebédszünet hagyott szusszanásnyi időt a hallottak feldolgozására, a kötetlenebb kapcsolatteremtésre. A szekciók tematikája széles spektrumon mozgott. A fent említett értelmezési keretből (valamint méretéből, térségben betöltött szerepéből, társadalmi, politikai és gazdasági súlyából) adódóan mennyiségileg kiemelkedett Oroszország: nemzetközi politikában elfoglalt helye, külpolitikájának irányvonalai, föderatív berendezkedésének sajátosságai, szomszédaival kialakított viszonyrendszere, védelmi politikája, sajátos határhelyzete (Kelet és Nyugat között) és nemzetépítésének egyedi vonásai egyaránt megjelentek, több nézőpontú bemutatásban.

A régiók szerinti szekcióbeosztás alapján a tudományos érdeklődés a kö- 
zép-ázsiai térség iránt igen intenzív: a nemzetépítés sajátos kérdései mellett a biztonságpolitika, a gazdasági perspektívák, az eurázsiai integrációs folyamatok, az autoriter hatalmi struktúrák és a társadalmi átalakulás kérdései is helyet kaptak. Önálló szekció foglalkozott a transzkaukázusi országokkal, a balti államokkal, a visegrádi országokkal és a Balkánnal, de érdekes módon a térség jelenlegi neuralgikus pontja, Ukrajna csak közvetetten (az orosz politika révén) kapott figyelmet. A területiség mellett különböző társadalmi jelenségek mentén csoportosított előadáscsokrok is jellemzőek voltak: identitás, nacionalizmus, vallás, az emberi jogok érvényesülése, a demokratikus társadalmi viszonyok értékelése és az átmenet (rendszerváltás) adták a válogatások alapját.

Változatos módszerek és elméleti keretek mentén megvalósuló kutatások eredményeit vagy éppen kezdeti fázisait mutatták be az elhangzó előadások, a társadalomtudományok nézőpontjainak gazdagságát felvillantva. Az előadások számából és a befogadóképesség határaiból adódóan csak szemezgetni lehet a programfüzet segítségével a változatos nézőpontok között. Az európai posztszovjet térséggel foglalkozó kutatócsoportunk számára elsődleges szempont volt annak felmérése, hogy etnikai földrajzi kutatásaink hogyan illeszkednek a térséggel foglalkozó társadalomkutatók vizsgálati irányaiba, milyen diskurzusok mentén végzik a nemzetközi szakértők a társadalmi folyamatok feltárását. A különböző nézőpontok relevanciáját mutatta ugyanannak a témának más elméleti keretek között történt eredményes újragondolása, amire a földrajzi lépték szerint mutatunk be példákat, egyúttal kiemelve a házigazda intézmény és ország perspektíváit, kiemelt témáit.

A birodalmi méretek, regionális léptékủ vagy országos szintü kutatások mögött „megbújva” a hétköznapok vizsgálata izgalmas társadalmi kérdéseket vetett fel a nagy múltú Narva városa kapcsán. Észtország legkeletibb városa a második világháború viszontagságaiban szinte teljesen elnéptelenedett, a szovjet megszállással újraszabták működési kereteit. A közeli uránbányák nyitása okán zárt várossá nyilvánította a szovjet hatalom, és szinte kizárólag oroszokat telepítettek területére. A rendszerváltás során függetlenné vált Észtország határvárosában így a lakosság zöme az egykori Szovjetunióból bevándorolt oroszajkú. Ez sajátos hétköznapokat eredményez az itt élőknek, miközben szimbolikus tartalmat kap a város, kilépve konkrét földrajzi méreteiből és gazdasági szerepköréből. A lakosság mindennapjaiban megjelenő, többszörös határhelyzetből adódó liminalitást követte nyomon Francisco Martinez (Helsinki Egyetem), míg szimbolikus jelentőségét, a másság mítoszának teremtését hangsúlyozta Heidi Erbsen (Tartui Egyetem), amelyet Edward W. Said munkája nyomán orientalizálásnak nevezett.

A balti államok - közöttük a házigazda Észtország - az orosz szomszédságot a 21. században is fenyegetésként élik meg, különösen a Krím félsziget katonai annexiója óta. A védelmi lehetőségek, illetve a kiszolgáltatottság feltárása kiemelt figyelmet kapott a konferencián. Ez a balti térség kapcsán megjelent katonai elemzésben (Giedrius Cesnakas, General Jonas Zemaitis Katonai Akadémia), ener- 
giagazdasági hálózatok vizsgálatában (Javad Keypour és Ivar Hendla, Tallinni Műszaki Egyetem) vagy éppen az információs technológia által létrehozott világ kiberhadszíntérként való értelmezésében (Alex Hardy, Londoni Egyetem).

Az orosz állam és az orosz nemzet, a nagy ellenfél, a „másik” megértésének jelentősége meghatározó motívuma volt a konferenciának. Ebben hasznos módszernek bizonyulhat a diskurzuselemzés. Kåre Johan Mjør (Uppsalai Egyetem) az orosz kormányzat konzervatív jellegének sajátos megjelenését emelte ki: a politikai nyilatkozatok szövegeiben tetten érhető múlt felé fordulást és az ezeréves orosz államiság hangsúlyozását az egykori szovjet vezetéstől való elkülönülés eszközeként értelmezte. Eric Vlaeminck (Edinburghi Egyetem) az orosz kormányzat által preferált szerző, Alekszandr Prokhanov művei alapján mutatta be azokat a motívumokat, amelyeket a politika az orosz nemzeti érzés propagandacélú erősítésekor felhasznál. Az oroszországi társadalomtudósok számára a megértés eszköze saját perspektívájukból adódóan módosult: az általuk bemutatott kutatások inkább kérdőívek, interjúk segítségével a hétköznapi ember által megélt orosz identitást igyekeztek feltárni (pl. Larisa Deriglazova, Tomszki Állami Egyetem).

A nemzeti identitás és a hozzá kapcsolódó nacionalizmusok vizsgálata kifejezetten a köztes-európai térhez kapcsolódott a konferencián (Szekciócímek: Identitás és nacionalizmus Közép- és Kelet-Európában; Nacionalizmus és demokrácia Közép- és Kelet-Európában; Kulturális hasadások és nacionalizmus Közép- és Kelet-Európában), a konferencia címében is megjelenő területek többi részén (különösen Közép-Ázsiában) inkább a nemzetépítéssel foglalkoztak a nemzetállami kereteken belül. Egyrészt az egykori keleti blokkhoz tartozó szatellitállamok kapcsán vizsgálták az európai integráció és a nacionalizmusok kölcsönhatásait (pl. James Headley, Otagói Egyetem), másrészt az európai szovjet utódállamokban jelentkező társadalmi feszültségeket generáló folyamatok hátterét mutatták be (pl. Illés Tamás, Eötvös Loránd Tudományegyetem).

A konferencia utolsó napjának reggelén tartott kerekasztal-beszélgetésen megjelentek mindazok a nézőpontok, amelyek mentén az előadások zöme értekezett a nemzetállami létről a térségben. A beszélgetést (A nemzetállami lét története Kelet-Európában: új kutatási irányok?) a konferencia főszervezője, a Tartui Egyetem professzora, Viacheslav Morozov moderálta. Lengyel (Dorota Kołodziejczyk), litván (Ivars Ījabs), orosz (Alexander Etkind) és ír (Róisín Healy) kollégáival folytatott beszélgetésében, valamint a hallgatóságtól érkező kérdések megválaszolása után összefoglalta a fő kutatási irányvonalat: a mindenkori Oroszországot egy alárendelt birodalomként aposztrofálta, amely gyarmatosítóként viselkedik a kelet-európai és az eurázsiai térségben, így a nemzetállami keretek működésének feltárásához a posztkolonialista nézőpontok lehetnek hasznosak.

A kellemes hangulatú, emberléptékü, kifogástalanul szervezett konferencia helyszínét adó egyetemi épületek, a történelmi emlékhelyekként is működő helyszínek, a körülöttük lévő ősfás parkok, a pezsgő életű, fiatalos egyetemi város terei tették még emlékezetesebbé a Kelet-Európával foglalkozó társadalom- 
tudósok találkozóját, mintegy élő történelemként foglalták keretbe a konferencián bemutatott jelenségeket, folyamatokat, nézőpontokat - a nemzetállami lét térségi sajátosságait.

\section{Köszönetnyilvánítás}

A konferencia-részvétel és a beszámoló a K 124291 számú, A poszt-szovjet után (?): A változó keleteurópai pufferzóna társadalmi folyamatainak földrajzi vizsgálata című projekt keretében, a Nemzeti Kutatási, Fejlesztési és Innovációs Hivatal (NKFIH) támogatásával valósult meg. 